Living with Others Inside the Self: Decolonising Transplantation, Selfhood and the Body Politic in Nalo Hopkinson's Brown Girl in the Ring

School of English and Languages

University of Surrey

Guildford

d.mccormack@surrey.ac.uk

01483686173

Keywords: organ transplantation, Nalo Hopkinson, Caribbean colonialism, Canadian politics, the body politic

Word count: 5990 


\section{Living with Others Inside the Self: Decolonising Transplantation, Selfhood and the Body Politic in Nalo Hopkinson's Brown Girl in the Ring}

\section{Decolonising the (Medicalised) Body of Science Fiction}

Organ transplantation is a staple of science fiction as it captures a scientific imaginary where the borders between life and death are blurred and where life is extended for some, while vulnerable others are exploited (largely for their organs). It renders visible medicine's role in instantiating embodied systems of inequality and violence, and therefore often figures in science fiction to highlight how medicine implements and reinforces colonial hierarchies of race, ability and sex. Responding to the relationship between medicine and colonial occupation as well as to science fiction's own repeated deployment of colonial ideologies, much work by contemporary science fiction writers of colour seeks to decolonise the genre both to critique ongoing colonial practices, in fiction and in broader society, and to imagine a more just postcolonial world ${ }^{1}$.

In this article, I examine how transplantation is a potent metaphor for re-imagining embodiment and its politics, particularly in the context of colonial histories of segregation in Nalo Hopkinson's Brown Girl in the Ring ${ }^{2}$. I explore how Hopkinson decolonises science fiction by explicitly bringing colonial histories of violence, racism and exclusion to the fore of her future world. In so doing, she reveals how contemporary biomedical practices of care, specifically transplantation, are central to the continued division of populations into those whose lives matter and those who are deemed disposable or useful only for their matter. I argue that Hopkinson builds on an historical tradition of using the body as a metaphor for the body politic by portraying 
donor and recipient bodies as the sites through which social injustice and violence can be visualised and a more just society imagined. Hopkinson exposes the contradiction of modern technologies of care which, in the case of organ transplantation, may save lives but are often dependent on a disposable population (of spare parts). Hopkinson's decolonisation of medicine not only reveals the discipline's ties to historical and contemporary injustice and violence, but also offers an alternative epistemology that builds on a tradition of Myalism. By turning to a stigmatised and purportedly nonscientific discipline - where science is understood as empirical and religion as nonevidence based beliefs - I suggest that Hopkinson undoes a long-standing hierarchy of epistemologies that segregate allopathic medicine from Myalism (and by extension other spiritual practices). Brown Girl in the Ring challenges historical, contemporary and future systems of segregation and violence by grappling with a knowledge system where selfhood is founded on a co-constitutive relationality, where the other is not separate or distant from the self, but rather the very means through which the self comes into being. Not only is the human re-imagined as emerging through its relationality with other humans, but its sense of being is constituted through an intimacy with the dead and the ancestors. In this context, Brown Girl in the Ring challenges the biomedical model of selfhood used in transplant therapy, which insists on a strict distinction and separation between living recipient and deceased donor ${ }^{3}$, by introducing Myalism as a valid epistemology of care and community building. I explore how the body politic is founded on this transplanted body - on a model of selfhood where self and other are formative of each other and may be alive, dead or the living-dead - both to bear witness to the continued violence against people of colour and to create a communal sense of belonging based on a relational and coconstitutive responsibility for each other. 
Brown Girl in the Ring focuses on three generations of black, Caribbean-Canadian women struggling to survive in a post-apocalyptic Toronto. The youngest daughter and main protagonist Ti-Jeanne is portrayed as increasingly unable to distinguish reality from her nightmare, future-revealing visions. Ti-Jeanne must listen to and learn from her grandmother Mami Gros-Jeanne to understand and not be allconsumed by her visions. Rather than diagnosing Ti-Jeanne's symptoms in an allopathic framework, Hopkinson situates these visions - and health and illness more generally - in a Caribbean and Yoruba tradition of Myalism. The shift towards Myalism reflects the novel's decolonisation of epistemologies that were demonised and outlawed by colonial law. More specifically, it captures how more than one being can exist in one body. This pan-African and specifically Caribbean incarnation of Mayalism is a turn to non-human or post-human beings and worlds and their relational intimacy with humans, which gives space to diverse understandings and experiences of health and illness.

While the novel offers an alternative understanding of the complex relationality between a living self and a deceased donor, it also posits the transplanted body as a potent re-configuration of the body politic. In this post-apocalyptic Toronto, the economy has collapsed, resulting in white flight from the centre to the suburbs. The downtown area is ruled over by a mafia-like group run by Rudy Sheldon, who we later learn is using a duppy - a human spirit captured in a bowl - to yield his power over the whole town and over life itself: 'Rudy does work the dead to control the living' (121). Asked to find a human heart for the Premier Uttley, Rudy forces TiJeanne's ex-partner Tony to kill a suitable donor, who turns out to be Mami Gros- 
Jeanne. Hopkinson does not portray a passive donor or an unchanged recipient, but rather shows a struggle inside the Premier's body, resulting in what is medically known as graft versus host disease. While the transplant doctors imagine the heart might kill the premier, the reader witnesses how Mami Gros-Jeanne allows for a peaceful co-existence between her heart and the recipient's body. The continuation of the life of the white Premier requires the killing of a black woman, showing how the maintenance of the white body politic is dependent on the invisible killing of people of colour. However, Mami Gros-Jeanne's willingness to work with the body she now inhabits gives recognition to how the other is constitutive of the self. In other words, Hopkinson's re-configuration of visceral co-constitutive relationality changes the body politic, demanding that the Premier share resources with those in Downtown Toronto. The transplanted body is a haunting reminder of the violence committed against people of colour to maintain the life of the white body (politic), but it is also the means through which a more just communal belonging is imagined.

\section{Selfhood, Zombies and Myalism}

Focusing on the endurance of the metaphorical use of the body to represent society in political discourse, Roberto Esposito argues:

Whether the danger that lies in wait is a disease threatening the individual body [or] a violent intrusion into the body politic, $[\ldots]$ what remains constant is the place where the threat is located, always on the border between the inside and the outside, the self and other, the individual and the common. ${ }^{4}$

It is precisely the formation of self and other that Brown Girl in the Ring reconfigures in order to imagine a body and a politic that does not murderously divide populations into worthy humans and disposable less than humans. The foundations for western philosophical thinking on how a being becomes a subject, comes to be 
recognised as human, are steeped in a hierarchical politics. Hegel posits a masterslave dialectic ${ }^{5}$, which as Frantz Fanon argues does not translate into a relationality of recognition but instead fixes the slave as an object of labour ${ }^{6}$. Similarly, Lacan's account of the mirror stage instantiates subject formation as moving from bodily dependence to a corporeally integrated self ${ }^{7}$. The infant as subject gains recognition as 'a singular self in a singular body' ${ }^{8}$. Margrit Shildrick affirms that both Cartesian (a clear split between the mind and the body) and Lacanian models disavow 'existential

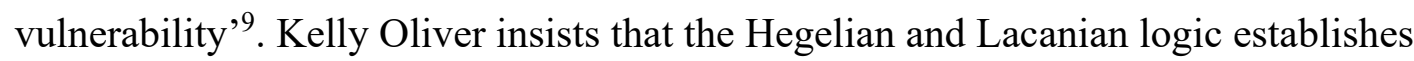
'a sense of lack, castration, or alienation, the sense of being cut off from the world' as central to subject formation ${ }^{10}$. Western philosophical understandings of self and other relationality are founded on distance and violence, and others are a potential threat to the integrity of the self. Here, the self must protect its borders to keep its (largely disembodied) self intact.

Judith Butler argues that the 'denial of [our] vulnerability through a fantasy of mastery (an institutionalized fantasy of mastery) can fuel the instruments of war' ${ }^{11}$. Thus, rather than denying the vulnerability of the body's and the body politic's borders, Butler, Oliver, Shildrick and others posit a model of subject formation based on vulnerability ${ }^{12}$, the monstrous ${ }^{13}$, love ${ }^{14}$, and a sense and experience of interrelationality ${ }^{15}$. I want to stress that subject formation emerges through, what Butler and Shildrick describe as, a pre-ontological tie. That is, self and other, while potentially independent as legal subjects, are responsible for each other, insofar as their very existence is dependent on the other. In Butler's words: 'For if I am confounded by you, then you are already of me, and I am nowhere without you'16. When subject formation is re-imagined through these queer, disability, postcolonial 
and feminist lenses then this intimate tie between self and other allows for a rethinking of social and political relationality and responsibility. This is not a segregationist politics; it is a politics where the self only emerges through its indebtedness to and responsibility for others. This is an indefinite responsibility, such that, as Jacques Derrida would argue, there must always be an infinite response to the call of others ${ }^{17}$.

Hopkinson firmly situates Mami Gros-Jeanne's role as a carer in a Caribbean tradition that colonial rule deemed witchcraft, unscientific and dangerous. When Tony turns to Mami Gros-Jeanne for help, fearing Rudy will slay him alive, Hopkinson describes in detail the ceremony that unfolds. There is the sacrifice of a willing chicken; cigar, rum and candy offerings; and the dramatic entry of the ancestral spirits (89-100). TiJeanne and her ex-partner Tony are portrayed as the scientifically sceptical younger generation, with Tony in particular representing a Canadian nursing perspective which is critical of Mami Gros-Jeanne's healing skills. He often derogatorily refers to her work as 'obeah' (104) and 'mumbo-jumbo' (98). The demonisation of Mami Gros-Jeanne's medical skills frames the novel, exposing tensions between two largely opposing epistemologies: western medicine and a Caribbean-based Myalism. Sarah Wood describes Tony's perception as 'colonial' ${ }^{18}$. Monica A. Coleman insists that the outlawing of African-based spiritual practices was a colonial endeavour not only based in religious conversion, but also intended to stamp out slave rebellions ${ }^{19}$. Thus, the continued existence of these spiritual practices in a futuristic Canada captures an enduring resistance to colonial and neo-colonial policies, practices and epistemologies. 
Myalism offers an alternative vision of how we might understand subject formation and our responsibility to others. Mami Gros-Jeanne calls on Eshu, 'the guardian of the streets, the crossroads of life and the boundaries between life and death ${ }^{20}$, to allow the ancestors to come forth. What the reader views, along with sceptical Tony, is TiJeanne and Mami Gros-Jeanne being possessed respectively by Prince of Cemetery and Papa Osain. This involves a physical change to their bodies: for the grandmother ‘[o]ne arm was missing and one leg' (97) and for Ti-Jeanne 'her legs seem longer than they were' (94), and both women become identifiable as men, through their physical appearances (Mami has 'an Adam's apple' (98)) and their 'deep' voices (94). Embodiment is altered and selfhood is multiplied as two beings co-exist in one body to the extent that the ancestors temporarily dominate the voice and external appearance of these humans. Losing a leg and an arm, changing gender, and speaking in the voice of an other may alter Mami Gros-Jeanne's and particularly Ti-Jeanne's sense of who they are, but it does not result in a loss or disintegration of self. The novel does not pathologise the connection between the dead, the ancestors and the living. Yoruba-based Caribbean Myalism gives space to a fantasy world where embodied selfhood is intertwined with others and where each person is always responsible for 'much more than oneself' ${ }^{21}$. This fantastical re-visioning is a decolonisation of epistemologies of selfhood, care and sociality, which in this postapocalyptic - and arguably in the contemporary - Canadian world are based on segregation, hierarchical difference and histories of violence. What is offered is a fantasy world where humans - through their embodied selves - are intimately connected to others, including to those whose existence may exceed the western philosophical definition of the human. 
However, Myalism is not offered as an alternative utopian vision, because everyday life in the future is still structured by the hierarchies, boundaries and exclusions of European colonial rule. A dangerous misuse of this epistemological tradition runs parallel to the transplant storyline: Rudy Sheldon abuses his knowledge of Myalism to gain youthfulness and longevity. Hopkinson thereby links his desires to those of transplant therapy, which promises to defy death and revive life even when one's own body parts are failing. He achieves these goals by turning his daughter MiJeanne/Crazy Betty into a zombie and trapping her spirit/self in a bowl as a soucouyant. Rudy's duppy is vampiric and is fed with the blood of the largely abandoned children of the downtown area. Life can only be extended when there is a disposable population; thus, the link is strengthened between the will to control life and death and the perpetuation of a violent socio-political order.

The creation of zombie-like beings, both Mi-Jeanne/Crazy Betty and Melba who labour endlessly for Rudy, is a haunting reminder of slavery. As Kyle William Bishop argues 'the zombie represents the ultimate imperialist dream - a slave laborer that is truly a thing, unthinking, un-aspiring, and non-threatening, ${ }^{22}$. Kaiama Glover suggests that the zombie 'is a being banned absolutely from participation in the political, entirely subject to the whims [...] of the sovereign ${ }^{\text {,23 }}$. By representing Rudy's abuse of Myalism, Hopkinson draws out how the enslavement of individuals and whole populations is dependent on and instantiates a model of subject formation where not all humans have access to the privileges of this category. When Rudy slays Melba alive, to deter his posse from any rebellion, we witness that ' $[\mathrm{z}]$ ombies are human beings against whom the most horrendous violence may be ethically perpetrated ${ }^{24}$. Once reduced to their bodies, zombies have no legitimate existence; their lack of 
subjectivity and humanness justifies the violence to which they can be subject. Here, self and other are separate, they are defined through hierarchical differentiation; and humanness is defined by a sovereign who reduces other subjects to 'bare life' ${ }^{25}$, solely to their flesh. Therefore Rudy can control both the extension of his own life and the unbearable continuation of life as a less than human being. Zombies and duppies remind readers that the division between life and death is a political question, as much as it is a medical definition.

\section{Spatialised Segregation and Its Embodied Histories}

Thus far I have suggested that subject formation, particularly the western philosophical tradition of hierarchical distanciation between self and other, is central to the violent process of dehumanisation and enslavement of individuals and populations. In this section, I explore how this process relates to space, particularly how the spatialised production of distinct populations is tied to the biotechnological need for spare viscera. In Brown Girl in The Ring the spatial organisation of the city and its suburbs is built on and reinforces class and race lines of purported hierarchical difference:

When Toronto's economic base collapsed, investors, commerce, and government withdrew into the suburb cities, leaving the rotten core to decay. Those who stayed were the ones who couldn't or wouldn't leave. The street people. The poor people. [...] Or [those] who saw the decline of authority as an opportunity. (4)

The fantasy of a future world where economic collapse results in white flight reveals a politics of segregation both in contemporary Canada and in the historical context of the Caribbean. Mr. Reed, the 'self-appointed town librarian' (10), makes a display of old newspaper headlines which chart the lead-up to the inner-city collapse: 
FEDERAL GOVT. CUTS TRANSFER PAYMENTS TO PROVINCE BY 30\%, CITES

INTERNATIONAL TRADE EMBARGO OF TEMAGAMI PINE

JOBLESS RATE JUMPS BY 10\%: TEMAGAMI LAWSUIT IS FUELLING ONTARIO

RECESSION, SAYS LABOUR MINISTER (11)

Michelle Reid argues that in the novel 'First Nations land claims are the catalyst that destabilise Canadian unity. They are an ongoing reminder of inequalities in the country; an unresolved legacy from [Canada's] beginning as a settler colony' ${ }^{26}$. The headlines refer directly to the federal government's dispute with the Temagami community, reinforcing the link between the fantastical world of Hopkinson's text, where no resources are allocated to the downtown area, and the reality of disputes concerning indigenous land and natural resources. Settler colony, as well as Caribbean colonial, histories seep through this fantasy future to reveal the continued structural violence of Canadian life.

The imagined space of segregation further exposes how a whole population may easily come to be imagined as 'disposable'27. Thinking with Giorgio Agamben's explanation of how segregation operates as a spatialisation of a legal state of exception, I would suggest that the novel shows how people may be killed for their organs without any legal ramifications. That is, 'the state of exception, which was essentially a temporary suspension of the rule of law on the basis of a factual state of danger, is now given a permanent spatial arrangement, which as such nevertheless remains outside the normal order' ${ }^{28}$. The novel conveys a future world where the law is suspended for those inhabitants in the centre. This space therefore comes to be inhabited by those who are 'less than human', and this 'equivocation of the human [...] forms the basis of the scepticism about the applicability of legal entitlements and protections' ${ }^{29}$. That these people are less than human, outside the laws that protect the 
whiter, richer humans in the suburbs, links the narration of this Caribbean family's life in Canada to the history of racialised segregation based on a system of enforced slave labour. Indeed, spatialised segregation operates to produce a zombified people. That is, a population which is almost dead but alive enough to be used as a warm resource for biotechnological interventions. Those living in the downtown area are reduced to bodies; the population is a wealth of biological resources for the extension of other lives.

Ann Laura Stoler ${ }^{30}$, Rebecca Skloot ${ }^{31}$, Anne McClintock ${ }^{32}$, among others, show how historically medicine has instantiated and facilitated violence towards others defined as inferior. Kalindi Vora argues that the 'antecedents of contemporary bioeconomies $[\ldots]$ were present in the economies of colonialism and slavery in which dehumanized and unfree workers were also self-reproducing capital'33. I would suggest that the ties between contemporary lifesaving therapies and colonial histories reveal not only an ongoing violence towards the most vulnerable, but also a spatialisation of care that facilitates the murder of specific populations. On learning that Mami Gros-Jeanne is a perfect match for Premier Uttley, Tony murders Mami Gros-Jeanne and calls in the Vultures (the name for the hospital paramedics who only enter the downtown area to take away the almost dead). The words of the Vultures contrast significantly with the murderous reality the readers have just witnessed:

\footnotetext{
'Angel of Mercy Hospital offers its condolences for your loss and thanks you and your family for making this life-giving donation of your loved one's biomaterial. Your address has been entered into the hospital's data banks and you will be compensated for your donation. Good day.' (153)
}

The words of these medics bring to the fore how altruistic - and often anonymised organ donation may conceal its violent practices and how a rhetoric of 'life-giving 
donation', which dominates transplant therapy, labours to detach organ donation from the very socio-political divisions and race and class hierarchies that may facilitate this biomedical intervention. Organ transfer is inseparable from politics and social structures, and this scene stresses that medical ethics cannot focus solely on miraculously saving lives but must also consider which lives are already negligible and therefore in their deadly disposability are facilitating such lifesaving possibilities. Mami Gros-Jeanne is zombie-like - a not-dead, breathing human under the control of others - because segregation facilitates legal murder. A spatialised necropolitics is not solely the capacity to exercise power over life and death, here it also extends over the definition of when life and death begin and end. Importantly, these re-definitions are only made possible through the spatialisation of such a biopolitical order that constitutes a population as less than human and thereby a breathing but not-living resource for whiter, richer others.

On the one hand, Mami Gros-Jeanne's murder is a patently obvious metaphor for how the subjugation of people of colour continues in Canada and how the medical sphere itself may require these divisive structures to continue its purportedly groundbreaking and lifesaving work. The novel shows that black, poor people can be murdered to save the lives of white, rich people, and that the system of transplantation fails to register such deaths as anything other than altruistic donation. Similar to other cultural productions ${ }^{34}$, this novel exposes how organ donation is intimately tied to colonial and neo-colonial medical practices. It further renders palpable how contemporary biotechnological interventions are dependent on vulnerable populations becoming donors. 
On the other hand, I would argue that the novel shows how such murders only occur when the body, including the body politic, is understood as a segregated entity. That is, the body politic is founded on a western philosophical tradition of subject formation as a structure of differentiated distance and hierarchies, which here enables the whiter, richer population to prey on or simply ignore those who exist outside the law of human protection. According to both Michel Foucault ${ }^{35}$ and Esposito, the medicalisation of a society requires 'prohibiting, or at least controlling, circulation in the name of public safety ${ }^{36}$. When Achille Mbembe describes how spatial reconfiguration is central to both historical and contemporary colonialism, he insists that segregation 'relegat[es] the colonized into a third zone between subjecthood and objecthood $^{37}$. Those segregated in downtown Toronto lack subject status and can therefore be murdered legally. Like the zombie slaves that Rudy creates and lords over, the downtown population for those in the suburbs lacks life. The life that is removed is not recognisable as a life, because life only exists in the suburbs, where we understand the suburbs as healthy and perpetuating segregationist power structures. For life to be maintained, a non-living - but a not-dead - resource must be extracted from a space imagined as diseased. The not-dead, but not-living, feed life into the suburban body and its politic, but they do this only through a legalised murder and only by separating the body's parts from its visceral system. Necropolitics is the segregation, management and controlling of life and death, but it is also redefining what it means to be alive and dead and to have one's intimate viscera be a valuable biological resource for those who live with the fantasy of eternal - white life.

\section{Graft Versus Host Disease and the Body Politic}


Describing his post-transplant sense of self, Jean-Luc Nancy states 'I am turning into something like a science-fiction android, or else [...] one of the living-dead' ${ }^{38}$. Brown Girl in the Ring grapples with this tension of whether the dead may live on by fictionalising the science of graft versus host disease. Mami Gros-Jeanne's murder does not result in a systemic disappearing of poor people of colour; rather, she returns dramatically in the form of a 'heart [that] was taking [...] over' Premier Uttley's whole body (237). While the Premier tries to tell the heart '[ $t]$ his is my body', reiterating the dominant paradigm of embodiment where we are "property owners of ourselves ${ }^{39}$, the heart exercises its power by 'completely paralyz[ing]' Uttley's body to the point where the latter realises she will 'no longer be herself' (237). On the one hand, such a fantastical post-death presence is a refusal to be silenced by the politicians who organised her murder, the medical practitioners who ignore the origin of the organ and those who murdered her (Rudy's mafia group). It is thereby symbolic of an anti-colonial and anti-racist resistance to socio-political institutions of segregation. On the other hand, it is also a direct engagement with what may occur in the body of an organ recipient post-transplantation. Hopkinson portrays a rare, but possible, occurrence in transplant medicine: graft versus host disease, where '[c]ells from the donor organ [attack] Uttley's immune system' (236). More common in transplantation is that the recipient's body rejects what is understood as an alien presence; immunosuppressants are used to dampen down the recipient's immune system so that recipient and donated organ may co-exist. Indeed, the rhetoric of immune therapy in transplantation is steeped in a socio-political imaginary of aggressive co-existence, where parts fight for their survival and immune systems battle a raging war to ensure the recipient valiantly lives on ${ }^{40}$. 
However, Hopkinson employs a fantasy of co-constitutive relationality to propose an alternative model of subject formation (particularly as it relates to post-transplant identity) and thereby a new vision of the body politic that resists violent segregation and divisive hierarchies. Similar to Nancy's description of his post-transplant self where he suggests the other is already of the self, Hopkinson conveys two beings in one body in her figuration of graft versus host disease:

The heart - her heart - was dancing joyfully between her ribs. When [Premier Uttley] looked down at herself, she could see blood moving through her body to its beat. In every artery, every vein, every capillary: two distinct streams, intertwined. She had worried for nothing. She was healed, a new woman now. (237)

Importantly, transplant teams reject the possibility of such post-death and posttransplant interrelationality ${ }^{41}$, which is different from many memoirs written by organ recipients who insist on an intimate connection between recipient and donor ${ }^{42}$. Graft versus host disease in Brown Girl in the Ring shows how the dead may live on, not in a horror-esque vision of a haunted self ${ }^{43}$ or in the fear of transplant teams that the patient will suffer a pathological identity crisis $^{44}$, but rather in an interdependent coconstitutive relationality. In other words, the self is already constituted by otherness, as the failing heart comes to be sensed as other to one's self $\mathrm{f}^{45}$ and as necessary to dispose of and replace with the heart of an other. However, a sense of wholeness cannot be restored, as a sealed off body is a fantasy of mastery which denies that the body is always already vulnerable to illness from within and without; there is no immunity from the other as that which is imagined as other - namely someone else's heart - gives vitality to the self and makes life possible. This is a decolonisation of colonial perceptions of Myalism and of transplant therapy. That is, this fantastical imagining suggests the dead are not quite dead and may even live on - in some altered form - inside an other. Put simply, this re-configuration of the transplanted 
body shows that changes in and to the body affect one's relation to both one's sense of self and those who died. In addition, this body conveys that alternative epistemologies may help develop understandings of post-transplant experiences that differ from the dominant paradigm in transplant care of a divisive split between surviving recipient and deceased donor.

That Caribbean epistemologies are essential to imagining another body politic, which is central to abolishing the deadly practices of segregation, is further reinforced by the parallel storyline where Ti-Jeanne fights the evil mafia lord Rudy by invoking not only the ancestors but also 'ghoul after ghoul, many of them children, all bearing the marks of Rudy's knife on their bodies' (225). She does this by bringing together worlds that are often deemed definitively separate:

For like the spirit tree that the centre pole symbolized, the CN Tower dug roots deep into the ground where the dead lived and pushed high into the heavens where the oldest ancestors lived. The tower was their ladder into this world. (221)

Hopkinson connects 'the techno-scientific architecture of the city [...] with the religious iconography of the Caribbean ${ }^{46}$. This image - which facilitates the arrival of multiple ancestors into Ti-Jeanne's body, portraying more than one, not always human, being in one body - instantiates another political order where the lines between the Caribbean and Canada, ancestral, dead and living, and self and other are opened in order to destroy the ongoing, neo-colonial, segregationist order. It is not, as Reid suggests, that this scene 'conveys [Ti-Jeanne's] sense of being connected to her heritage, while also being at home in Canada ${ }^{947}$, rather it captures how that which is deemed other and therefore separate from Canada is in actual fact integral to and constitutive of life itself. What constitutes Canada is not only its idealised image of multiculturalism, but also its colonial history in the Caribbean, its ongoing 
colonisation of indigenous lands, a politics of segregation and a deadly health care system. Self and other are relational and constitutive and the Jab-Jab, 'a devilish creature of Jamaican and Trinidadian carnival that can also be understood as the Prince of Cemetery manifestation of [Eshu] ${ }^{\text {, }}$, tells Ti-Jeanne: 'And child, you do a thing I never see nobody do before. For a few minutes there, you hold eight of the Oldest Ones in your head one time' (229). Ti-Jeanne is simultaneously herself and coexisting with the ancestors who also manifest as distinct beings. Selfhood is more than one being in one body, while still remaining attached to a sense of a singular identity that is evidently intertwined with the bodies and minds of more than human others. Indeed, a belief in the dead being able to assist the living, along with a strong sense of interrelationality with the ancestors, facilitates the defeat of the murderous mafia group. To this extent, Brown Girl in the Ring uses science fiction to allow for the possibility that spatial and embodied reality is shared with others from realms that are deemed fictional or even impossible. It is a decolonisation of medical knowledge from the perspective of a fictionalised science based both in the real possibility of graft versus host disease and the existence of ancestral beings and living-dead humans.

This body re-formed through graft versus host disease, the ties between the dead, the living and the ancestral, and the connections between the technological and the spiritual, is the foundation for imagining a new politics. When Premier Uttley awakens from her coma, she is keen to create a system for organ donation where the 'bodies [of those who opt-out] will never be touched' (239). She also insists that she is going to 'rejuvenate Toronto' (239) because she believes 'there are quite a few resourceful people left' downtown (240). Rather than figuring the immune system as 
a military defence system, Brown Girl in the Ring captures an imaginary whereby the other is constitutive of the self not as a destructive or deadly force but as the source of vitality that was lacking in one's own organ(s). It is a haunting reminder of both how death constitutes life and our indebtedness to others for survival. The body politic is no longer envisioned as a segregation-based spatialisation of populations; rather, the recognition that the other is already of the self and essential to continued life opens up a space for change and for responsibility for each other. This is not an idealisation of a future togetherness, but a visceral reminder of both the disposability of black lives and the violence necessary to maintain the white body politic. However, Mami GrosJeanne refuses to let the white body (politic) continue on unchanged. Although legally dead, Mami Gros-Jeanne fights for justice not in the form of the continuation of her own life, but by demanding resources for inner-city life. The flesh of the dead does not simply become a passive object, but rather fights to change both the shared space within which it exists and the segregated world of Toronto.

In Brown Girl in the Ring the overwhelming need to prolong - and control the meaning of - life is the impetus for murder. The creation of zombies is a haunting reminder of slavery and thus of how a colonial order continues to structure everyday Canadian life. My aim throughout this article has been to show an intimate link between space and biotechnological interventions, to reveal how a politics of segregation facilitates a deadly health care system. The body as distinct and separate from others is the biomedical model for transplant therapy and as such refutes any post-transplant experience of a tie between the living recipient and the deceased organ donor. Hopkinson offers an entry point into re-imagining knowledge of transplantation by proposing a decolonisation of Myalism, an epistemology 
repeatedly stigmatised and invalidated by European colonial rule. The resilience of Myalism is evidence of a mode of survival that gives space to accounts that fall outside of established narratives and epistemologies. Importantly, it insists that living humans can co-exist with those deemed dead or ancestral. The novel is not utopian in vision and it critiques both Myalism and organ donation when these systems seek solely to extend the lives of certain individuals at the expense of the poor, people of colour, women, people with disabilities and queers. Brown Girl in the Ring suggests that health care is not only about treating individuals or specific illnesses but also about considering the social and political contexts that make such life extensions possible. Science fiction by women of colour renders palpable what is at stake in failing to register how lives come to matter and how matter can be sourced from those deemed lacking vitality.

The theory of embodiment offered by both graft versus host disease and Myalism gives attention to the co-constitutive relationality of self and other and serves to interrogate the biomedical model of selfhood central to transplantation. Hopkinson goes to the core of the "transplant imaginary' 49 by re-imagining the immune system through the scientific possibility of graft versus host disease. Rather than a raging war machine, the immune system is figured as accommodating more than one being in one body. Esposito's description of how the immune system works captures the potential of Hopkinson's re-imagined body (politic):

The equilibrium of the immune system is not the result of defensive mobilization against something other than self, but the joining line, or the point of convergence, between two divergent series. [...] Its quality is not measured by its ability to provide protection from a foreign agent, but from the complexity of the response that it provokes. [...] At its foundation 
there does not lie the remembrance of an uncontaminated genetic principle, but the experience of its own original alteration. ${ }^{50}$

Outside and inside, self and other are not dividing lines of separation but the join, the very constitutive contact that brings about change. In Brown Girl in the Ring, the Premier undergoes an immune response, where the murdered Mami Gros-Jeanne dominates the DNA of the Premier, demanding visceral and political change. Visceral relationality is re-imagined and a co-constitutive responsibility for each other emerges as a metaphor for political belonging. Yet the novel is cautious, as the possibility for change - unlike in Esposito's formulation - is achieved at the expense of yet another killing of a black woman. Mami Gros-Jeanne's struggle to de-segregate space is a call to remember how the white body politic thrives on the zombification of black bodies and how contemporary biotechnological interventions must be wary of repeating such histories of violence. Re-configuring the body, the very relational means through which subjects emerge, is the foundation for changing politics to allow resources to be shared. The body politic is responsive and it remembers, and in so doing it is the potential for ongoing responses to the changing needs of diverse peoples and epistemologies. There is no original body or politic, only the response; it is a call to respond and to change over and over again in a co-constitutive relationality with everchanging others.

\footnotetext{
${ }^{1}$ For discussions on science fiction and race, see, for example: Rutledge, GE. Nalo Hopkinson. digitalcommons.unl.edu/englishfacpubs/25 2002: 1-22; Nama, A. Black Space: Imagining Race in Science Fiction Film. Austin: University of Texas Press, 2008; and Nelson, A. Introduction: Future Texts. Social Text 2002; 20(2): 1-15.

${ }^{2}$ Hopkinson, N. Brown Girl in the Ring. New York: Hachette, 1998. This novel will be referenced in the body of the article with page numbers in parentheses.
} 
${ }^{3}$ See, for example: Sharp, LA. Strange Harvest: Organ Transplants, Denatured Bodies and the Transformed Self. Berkeley: University of California, 2006.

${ }^{4}$ Esposito, R. Immunitas: The Protection and Negation of Life. Translated by Zakiya Hanafi. Cambridge: Polity Press, 2013 (2).

${ }^{5}$ Hegel, GWF. Phenomenology of Spirit, trans. by A. V. Miller. Oxford: Clarendon Press, 1977 (115).

${ }^{6}$ Fanon, F. Black Skin, White Masks. Translated by Charles Lam Markmann. London: Pluto Press, 1967 (220).

${ }^{7}$ Lacan, J. Ecrits: A Selection. Translated by Alan Sheridan. London: Routledge, [1966] 1977 (2 and 5).

${ }^{8}$ Shildrick, M. Embodying the Monster: Encounters with the Vulnerable Self.

London: Sage Publications, 2002 (105).

${ }^{9}$ Ibid. (106).

${ }^{10}$ Oliver, K. Witnessing: Beyond Recognition. Minneapolis: University of Minnesota Press, 2001 (189).

${ }^{11}$ Butler, Precarious Life: The Powers of Mourning and Violence. London and New York: Verso, 2004(a) (29).

${ }^{12}$ Ibid.

${ }^{13}$ Shildrick. 2002.

${ }^{14}$ Oliver. 2001.

${ }^{15}$ McCormack D. Queer Postcolonial Narratives and the Ethics of Witnessing. New York: Bloomsbury, 2014.

${ }^{16}$ Butler. 2004(a) (49), emphasis added.

${ }^{17}$ Derrida, J. The Principle of Hospitality. Parallax 2005; 11(1): 6-9.

${ }^{18}$ Wood, S. 'Serving the Spirits': Emergent Identities in Nalo Hopkinson's Brown Girl in the Ring. Extrapolation 2005; 46(3): 315-326 (320).

${ }^{19}$ Coleman, MA. Serving the Spirits: The Pan-Caribbean African-Derived Religion in Nalo Hopkinson's Brown Girl in the Ring. Journal of Caribbean Literatures 2009; 6(1): $1-13$.

${ }^{20}$ Ibid. (7).

${ }^{21}$ Butler J. Undoing Gender. London: Routledge, 2004(b) (16).

${ }^{22}$ Bishop, KW. American Zombie Gothic: The Rise and Fall (and Rise) of the Walking Dead in Popular Culture. Jefferson: McFarland, 2010 (70).

${ }^{23}$ Glover, KL. New Narratives of Haiti; or, How to Empathize with a Zombie. Small Axe 2012; 16(3): 199-207 (202).

${ }^{24}$ Cohen, JJ. Undead (A Zombie Oriented Ontology). Journal of the Fantastic in the Arts 2012; 23(3): 397-412 (401).

${ }^{25}$ Agamben, G. Homo Sacer: Sovereign Power and Bare Life. Chicago: Stanford University Press, 1998.

${ }^{26}$ Reid, M. Crossing the Boundaries of the 'Burn': Canadian Multiculturalism and Caribbean Hybridity in Nalo Hopkinson's Brown Girl in the Ring. Extrapolation 2005; 46(3): 297-314 (302).

${ }^{27}$ Butler, 2004(a) and Mbembe, A. Translated by Libby Meintjes. Necropolitics. Public Culture 2003; 15(1): 11-40.

${ }^{28}$ Agamben. 1998 (168-9).

${ }^{29}$ Butler, 2004(a) (74).

${ }^{30}$ Stoler, AL. Race and the Education of Desire: Foucault's History of Sexuality and the Colonial Order of Things. Durham: Duke University Press, 2000.

${ }^{31}$ Skloot, R. The Immortal Life of Henrietta Lacks. London: Pan Macmillan, 2011. 
${ }^{32}$ McClintock, A. Imperial Leather: Race, Gender and Sexuality in the Colonial Conquest. New York: Routledge, 1995.

${ }^{33}$ Vora, K. Life Support: Biocapital and the New History of Outsourced Labor. Minneapolis, MN: University of Minnesota Press, 2015 (7).

${ }^{34}$ An excellent example of a fictionalised look at the trade in organs is: Frears, S. (Dir.) Dirty Pretty Things [DVD]. UK: BBC Films, 2002. For examples of extensive anthropological work on organ transfer, see: Scheper-Hughes, N. The Last Commodity: Post-Human Ethics and the Global Traffic in 'Fresh' Organs. In A. Ong and SJ. Collier (eds.). Global Assemblages: Technology, Politics, and Ethics as Anthropological Problems. Malden, MA: Wiley-Blackwell, 2005: 145-167; and Cohen, L. Operability, Bioavailability, and Exception. In A. Ong \& S. J. Collier (Eds.). Global Assemblages: Technology, Politics, and Ethics as Anthropological Problems. Malden, MA: Wiley-Blackwell, 2005: 79-90.

${ }^{35}$ Foucault, M. Discipline and Punish: The Birth of the Prison. Translated by A. Sheridan. New York: Random House, 1977 (228).

${ }^{36}$ Esposito. 2008 (140).

${ }^{37}$ Mbembe. (26).

${ }^{38}$ Nancy, J-L. Corpus. Translated by RA. Rand. New York: Fordham University Press, 2008 (170).

${ }^{39}$ Cohen, Ed. A Body Worth Defending: Immunity, Biopolitics and the Apotheosis of the Modern Body. Durham: Duke University Press, 2009 (81).

${ }^{40}$ For an analysis of representations of immune systems in memoirs and fiction, see McCormack, D. Intimate Borders: The Ethics of Human Organ Transplantation in Contemporary Film. Review of Education, Pedagogy and Cultural Studies 2012; 34(3-4): 170-183.

${ }^{41}$ See, for example: Fox R. and Swazey J. Spare Parts: Organ Replacement in American Society. Oxford: Oxford University Press, 1992.

${ }^{42}$ See, for example: Sylvia, C. with William Novak. A Change of Heart: The Extraordinary Story of a Man's Heart in a Woman's Body. London: Little, Brown, 1997.

${ }^{43}$ The horror genre is fascinated with organ transplantation. See, for example:

Moreau, D. (Dir.) The Eye [DVD]. USA: Lionsgate, 2008.

${ }^{44}$ For an excellent analysis of the pathologisation of organ recipient experiences, see: Sharp, LA. Strange Harvest: Organ Transplants, Denatured Bodies and the Transformed Self. Berkeley: University of California, 2006.

${ }^{45}$ Nancy. 2008 (162-63).

${ }^{46}$ Wood. 2005 (324).

${ }^{47}$ Reid. 2005 (310).

${ }^{48}$ Coleman. 2009 (10).

${ }^{49}$ McCormack, D. The Transplant Imaginary and Its Postcolonial Hauntings. In E. Malmqvist and K. Zeiler (eds.). Bodily Exchanges, Bioethics and Border Crossing. London: Routledge, 2016: 135-152.

${ }^{50}$ Esposito. 2013 (174). 